\title{
Growth and Yield Response of Wheat to Tillage, Rice Residue and Weed Management under Rice-Wheat Cropping System
}

\author{
Bisheshwor Prasad Pandey ${ }^{1^{*}}$, and Tanka Prasad Kandel ${ }^{2}$ \\ ${ }^{1}$ National Wheat Research Program (NWRP), Rupandehi, Nepal \\ ${ }^{2}$ Noble Research Institute, LLC, Ardmore, OK 73401, USA
}

\section{MANUSCRIPT INFO}

Article history:

Received 14 February 2019

Received in revised form 13 August 2019

Accepted 26 December 2019

\section{Keywords:}

Crop residue

Herbicides

Tillage system

Wheat yield

\begin{abstract}
A B S T R A C T
Recent decades have seen many changes in agricultural production systems in Nepal, such as increased mechanization for harvesting of major cereal crops, which leaves a large volume of crop residue in the field, increased herbicide application for weed control, and increased adoption of reduced tillage systems. In this study, we compared the effects of tillage, rice residue and weed managements on yield and yield attributes of wheat cultivated under rice-wheat rotation in the Southern Plain (Terai) region of Nepal. The study was conducted during the wheat growing seasons (November through April) of 2013-2014, 2014-2015 and 20152016 in Rupandehi district. The experiment was deployed in a split-split plot design with tillage system as main plot [conventional tillage (CT) and zero tillage (ZT)], residue removal management as a sub-plot [whole residue retained (WR), partial residue retained (PR) and no residue retained (NR)], and weed management as a subsub plot [(manual weeding $(\mathrm{MW})$ and chemical weeding $(\mathrm{CW})]$, replicated three times. Analysis of variance was applied to the yield and yield attributes of wheat for fixed and interaction effects. Averaged across the years, the CT system $\left(2.4 \mathrm{t} \mathrm{ha}^{-1}\right)$ had significantly higher yield than ZT $\left(2.2 \mathrm{t} \mathrm{ha}^{-1}\right)$ but the difference was not consistent in all study years. While rice residue retention did not influence grain yield in Year1, WR produced greatest and NR produced lowest yield in Year2 and Year3, indicating potential yield increase in wheat following the whole rice residue retention in the long run. Grain yield did not significantly vary with weed management method, suggesting that manual weed control can be as effective as herbicide in weed management in wheat agroecosystem in the Southern Plains (Terai) region of Nepal.
\end{abstract}

(C) 2019 NAPA. All rights reserved.

\section{Citation:}

Pandey, B. P., \& Kandel, T. P. (2019). Growth and Yield Response of Wheat to Tillage, Rice Residue and Weed Management under Rice-Wheat Copping System. Global Journal of Agricultural and Allied Sciences, 1(1): 43-48

\section{Introduction}

Wheat (Triticum aestivum L.) is the most important and strategic cereal crop for the majority of the world's populations. In the Indo-Gangetic Plains (IGP), which is considered a bread basket of South Asia including most of northern and eastern India, eastern Pakistan, most areas of Bangladesh and the southern plains of Nepal (Terai), wheat is the major crop (Pathak et al., 2003). As in most of the areas in the IGP, wheat is mostly cultivated in rotation with rice (Oryza sativa L.) in Nepal, with a total acreage of 0.73 million ha in 2016 (Ministry of Agricultural Development, 2017).

Tillage is commonly practiced in conventional agriculture to create a soil environment favorable for crop establishment and growth, but it may adversely affect long-term productivity of soil due to increased loss of soil organic matter (Mathew et al., 2012). In the IGP, both rice and wheat crops are generally cultivated under conventional tillage (CT) systems. However, cultivation of wheat under a zero tillage (ZT) system is increasing as it allows early planting of wheat (Hobbs \& Giri, 1997). The ZT system also increases retention of soil moisture, which is a critical factor for wheat production in the region. Likewise, a ZT system is effective in controlling bunchgrass (Phalaris minor Ritz.), which is a notorious weed in the region (Erenstein \& Laxmi, 2008). Field trials across South Asia have demonstrated that ZT system may maintain or increase wheat yields while using less energy and irrigation for cultivation (Erenstein \& Laxmi, 2008; Gathala et al., 2013).

Traditionally, wheat and rice in the IGP are harvested manually and straw is removed from the field to use as forage, despite the poor forage quality of rice straw due to high silica content (Mandal et al., 2004). Although manual harvesting is still a common practice, mechanized harvesting is increasing rapidly in the region. In mechanized harvesting systems, a large volume of rice straw is left in the field, which interferes with the operations of the seed drill used for wheat planting. Therefore, farmers generally burn rice straw prior to planting of wheat (Gupta et al., 2004). Burning crop residues not only contributes to carbon and nitrogen losses of the ecosystem, but it also increases air pollution and emissions of greenhouse gases to the atmosphere (Sahai, Sharma, Singh \& Gupta, 2011). Indeed, increased air pollution during rice straw burning periods has

* Corresponding author. E-mail address: bisheshworpandey2009@gmail.com 
become a serious recurring environmental problem in large cities in northern India and southern Nepal (Singh et al., 2018). Therefore, there is an urgent need to develop agronomical managements to avoid rice straw burning in the region. If straw is retained in the field, it may help to improve soil physical and chemical properties, and ecological functions as straw provides plant nutrients and soil organic matter (Wang et al., 2015). The straw used as mulch also helps to reduce evaporation and soil temperature, and increases soil infiltration (Ram, Dadhwal, Vashist \& Kaur, 2013). As a mulch layer, the straw helps to suppress weed emergence and growth, which is a serious problem under a ZT system of wheat (Nawaz et al., 2017). Indeed, a recent global meta-analysis has indicated that the yield benefits of conservation tillage systems are achieved only if permanent soil cover of crop residues is maintained (Pittelkow et al., 2015).

In addition to tillage and residue managements, weed management is also an important crop management activity to improve productivity of wheat. In Nepal, where most of the rice-wheat farms are smaller than one hectare, weed is traditionally removed by hand and often used as forage for cattle. However, usage of herbicide is increasing due to shortage of labor in recent decades associated with emigration of the working population (Rao et al., 2017).

Many field studies were conducted in the IGP during the last two decades to understand tillage, residue and weed managements on wheat grain yield (Choudhary \& Behera, 2013; Gangwar, Singh, Sharma, \& Tomar, 2006; Jain, Jain, Mishra, \& Kewat, 2007; Mandal et al., 2004; Ram et al., 2013). However, the field trials were mostly conducted in the westerly parts of IGP in India. Thus, information on tillage, rice-residue and weed managements on growth, yield and yield attributes of wheat in southern Nepal, which is considered as a grain bowl of the country, are scarce. Therefore, this field study was conducted to examine the effects of tillage systems (zero and conventional tillage), rice residue retention (whole, partial and no-retention), and forms of weed management (manual and chemical).

\section{Materials and Methods}

\subsection{Experimental site and environmental conditions}

The study was conducted at the research farm of the National Wheat Research Program (NWRP) near Bhairahawa in western Nepal (27 $31^{\prime} 49^{\prime \prime}$ $\mathrm{N}, 83^{\circ} 27^{\prime} 36^{\prime \prime} \mathrm{E}$ and $82 \mathrm{~m}$ above sea level). The climate is of sub-tropical type with three distinct seasons: summer, rainy and winter. Detailed descriptions of soil physical and chemical properties are given by Khadka et al. (2015). In brief, the texture is classified as silt loam to silty clay loam. Average soil organic matter content was $2.5 \%$ and total $\mathrm{N}$ content was $0.14 \%$. The soil was mildly alkaline, with average soil $\mathrm{pH}$ of 7.9 . This study site lies within C - block of the NWRP farm map (Khadka et al., 2015).

The experiment was conducted during the wheat growing seasons (November through April) of 2013-14, 2014-15 and 2015-16, hereinafter referred to as Year 1, Year 2 and Year 3, respectively. The meteorological data of the three wheat growing seasons in comparison to long-term data are presented in supplementary Figure 1. Precipitations during the wheat growing season of Year $1(59 \mathrm{~mm})$ and Year $3(31 \mathrm{~mm})$ were lower than long-term average precipitation $(157 \mathrm{~mm})$ while it was higher in Year 2 (321 mm). The amounts of precipitation in March and April of Year 2 wheat growing season were particularly higher than the long-term averages in those months. Average maximum daily temperature during the wheat growing season of Year $1\left(26.9^{\circ} \mathrm{C}\right)$ and Year $2\left(26.4^{\circ} \mathrm{C}\right)$ was lower than long-term average $\left(27.9^{\circ} \mathrm{C}\right)$ while it was higher in Year $3\left(29.1^{\circ} \mathrm{C}\right)$. Average minimum daily temperature during the wheat growing season of Year 1 $\left(14.9^{\circ} \mathrm{C}\right)$ and Year $2\left(15.0^{\circ} \mathrm{C}\right)$ was greater than long-term average $\left(14.6^{\circ} \mathrm{C}\right)$ while it was lower in Year $3\left(13.7^{\circ} \mathrm{C}\right)$. Average minimum temperatures in March during all three study years were particularly lower than the longterm average.

\subsection{Experimental design, treatments and crop management}

The experiment was deployed in a split-split plot in a randomized complete block design with tillage system [conventional tillage (CT) and zero tillage (ZT)] as main plots. Main plots were split into sub-plots at three levels of rice residue management treatment as whole (WR), partial (PR), and no (NR) rice residue retention. In WR management, all aboveground residues of rice were chopped and left in the plots as mulch after wheat planting. In PR management, the bottom $20 \mathrm{~cm}$ of rice straw was left in the field. In NR management, all rice residue was removed and not returned as mulch. The sub-plots were further split into two forms of weeding as manual (MW) and chemical $(\mathrm{CW})$. Thus, there were a total of 12 treatment combinations with 3 replicated plots $(4 \mathrm{~m} \times 4 \mathrm{~m})$ in each combination. The experiment was repeated with the same plot layout in all three years of the study. Tillage and herbicide management treatment plots received identical tillage and herbicide treatments during the rice season to minimize the confounding effect of prior crop management practices.

In each study year, rice was planted in June-July and harvested in November. After rice harvest, wheat (cv. Vijay) was sown @ $120 \mathrm{~kg} \mathrm{ha}^{-1}$ at east-west row direction with $18 \mathrm{~cm}$ row spacing that resulted in 22 rows per plot. Vijay is a recently released wheat cultivar for the Terai region of Nepal (Timsina et al., 2018). The grain yield of wheat was determined by harvesting the crop from central $7.2 \mathrm{~m}^{2}$ area from each plot.

The timeline of field operations during the three study years is presented in supplementary Table 1. First irrigation was applied at crown root initiation (GS 21; Zadoks, Chang \& Konzak, 1974) and the second irrigation was applied around booting stage (GS 41-47) of wheat. Irrigation was applied with flooding on the surface. All plots received inorganic fertilizer at the rate of 100:50:25 kg N:P:K (nitrogen, phosphorus, potash) $\mathrm{ha}^{-1}$ at planting of wheat as urea (46:0:0 N:P:K), di-ammonium phosphate (18:46:0 N:P:K) and muriate of potash $(0: 0: 60 \mathrm{~N}: \mathrm{P}: \mathrm{K})$. Half rate of $\mathrm{N}$ and full rate of $\mathrm{P}$ and $\mathrm{K}$ fertilizers were applied at sowing of wheat. The remaining half of $\mathrm{N}$ was applied as top dressing of urea within a week of the first irrigation. Glyphosate (1.0 kg active ingredient ha $\left.{ }^{-1}\right)$ was sprayed in $\mathrm{CW}$ plots prior to planting of wheat. During the crop growing period of wheat, $\mathrm{CW}$ plots were treated with 2, 4-D $\left(0.8 \mathrm{~kg}\right.$ active ingredient ha $\left.{ }^{-1}\right)$ in Year 1 and Sulfosulfuron $\left(0.025 \mathrm{~kg}\right.$ active ingredient $\left.\mathrm{ha}^{-1}\right)$ in Year 2 and Year 3 to control weeds. Nuvan (dichlorvos) was sprayed once in Year 3 to control insects.

\subsection{Measurements of growth and yield traits}

Plant growth was recorded on 50 marked plants in each plot. A specific crop stage was considered reached when $75 \%$ plants showed the characteristics of that phase, and number of days were counted from the date after sowing (DAS). Plant height and spike length were measured from randomly selected 10 plants per plot at physiological maturity (GS 93). Spikes from the 10 plants were sampled to count grains per spike. Number of effective tillers per square meter were also counted at physiological maturity (GS 93) from 1- $\mathrm{m}^{2}$ areas in each plot.

After final harvesting, the crop was sun-dried, threshed, cleaned and grain was sun-dried again. Grain yield was adjusted at $12 \%$ moisture since 
the grain was sun-dried instead of oven-dried. Thousand grain weight was determined by weighing 1000 kernels from each plot.

\subsection{Statistical analysis}

Replicated measurements from each plot were averaged prior to statistical analysis. Effect of study years, tillage, residue and weed managements and their interactions were analyzed by analysis of variance (ANOVA) using a PROC GLIMMIX procedure in SAS software (version 9.3, Cary, NC, USA). Block and study years were treated as random variables. Treatment means were separated by the least significance difference (LSD) at $5 \%$ probability level.

\section{Results}

\subsection{Plant height and tiller density}

Plant height was not influenced by tillage system in any of the study years (Table 1). However, averaged over three years, the CT system had significantly taller plants than in the ZT system. Rice residue management had no significant effect on plant height in Year 2 and Year 3 but WR had the tallest and NR had the shortest plants in Year 1. Likewise, averaged across three years, WR had the tallest and NR had the shortest plants. The method of weed management did not influence plant height in Year 1 and 2 but the plants were significantly taller under MW than CW in Year 3. Likewise, averaged across three years, plants were taller under MW compared to CW. Averaged across the treatments, plants were tallest in Year 3 and shortest in Year 1. Two- and three-way interaction effects of tillage, residue and weed managements were not significant on plant height (Supplementary Table 2).

Effective tiller density (number of tillers per square meter) of wheat was greater under the CT system than the ZT system in Year 1 and Year 2. However, tiller density was similar under both tillage systems in Year 3. Averaged across years, the CT had more effective tillers than ZT. Rice residue and weed managements did not influence tiller density in any of the study years. Averaged across treatments, plants had fewer effective tillers in Year 1 than in Year 2 and Year 3. Interaction effects between residue and weed management were significant as the MW weed management under WR residue treatment had the highest tiller density but the same weed management had the lowest tiller density under NR (Supplementary Tables $2,3)$.

Table 1. Effects of different tillage, crop residue and weeding management practices on plant height and effective tiller density of wheat.

\begin{tabular}{|c|c|c|c|c|c|c|c|c|}
\hline \multirow{2}{*}{ Treatment } & \multicolumn{4}{|c|}{ Plant height (cm) } & \multicolumn{4}{|c|}{ Effective tiller density $\mathbf{m}^{-2}$} \\
\hline & Year 1 & Year 2 & Year 3 & Average & Year 1 & Year 2 & Year 3 & Average \\
\hline \multicolumn{9}{|l|}{ Tillage practice } \\
\hline Conventional (CT) & 90.4 & 92.9 & 102.1 & $95.1 \mathrm{a}$ & $208 \mathrm{a}$ & $295 a$ & 247 & $250 \mathrm{a}$ \\
\hline Zero tillage (ZT) & 88.6 & 92.6 & 100.1 & $93.8 b$ & $146 b$ & $220 \mathrm{~b}$ & 230 & $199 \mathrm{~b}$ \\
\hline \multicolumn{9}{|l|}{ Rice residue management } \\
\hline Whole retention (WR) & $92.0 \mathrm{a}$ & 93.2 & 102.0 & $95.8 \mathrm{a}$ & 174 & 272 & 250 & 232 \\
\hline Partial retention (PR) & $89.2 b$ & 92.8 & 100.9 & $94.3 b$ & 190 & 257 & 237 & 228 \\
\hline No retention (NR) & $87.3 \mathrm{c}$ & 92.3 & 100.4 & $93.3 \mathrm{c}$ & 168 & 244 & 229 & 214 \\
\hline \multicolumn{9}{|l|}{ Weed management } \\
\hline Manual weeding (MW) & 90.0 & 92.9 & $101.8 \mathrm{a}$ & $94.9 \mathrm{a}$ & $176 \mathrm{a}$ & 260 & 240 & 225 \\
\hline Chemical weeding $(\mathrm{CW})$ & 89.0 & 92.6 & $100.4 \mathrm{~b}$ & $94.0 \mathrm{~b}$ & $179 a$ & 255 & 237 & 224 \\
\hline Average & $89.5 \mathrm{C}$ & $92.7 \mathrm{~B}$ & $101.1 \mathrm{~A}$ & & 177B & $258 \mathrm{~A}$ & $238 \mathrm{~A}$ & \\
\hline
\end{tabular}

Note: Different lowercase letters within a column indicate significant difference $(P<0.05)$ between sub-plot treatments within main-plot crop management treatment. Different uppercase letters within a row of annual mean values (last row) indicate significant difference among the study years within each crop growth parameter.

\subsection{Days to heading and maturity}

The tillage system did not influence days to heading in Year 1, but the CT system had an earlier heading stage than the ZT system in Year 2 and Year 3, albeit difference was within two days (Table 2). Averaged across years, plants under CT reached heading stage earlier than under ZT. The effect of rice residue management on days to heading was not significant in Year 1 and Year 2 but plants under NR took 2 additional days $(P<0.05)$ to reach the heading stage than the plants under WR in Year 3. Weed management did not influence days to heading in any of the study years. Averaged across treatments, heading stage was reached early in Year 2 and late in Year 3. Two- and three-way interaction effects of tillage, residue and weed managements on days to heading were not significant (Supplementary Table 2).

Tillage system did not influence days to maturity in Year 1, but plants under CT system reached to maturity earlier $(P<0.05)$ than ZT system in Year 2 and 3 (Table 2). Likewise, averaged across years, plants under CT reached heading stage earlier than ZT. Rice residue management did not have a consistent year-to-year effect on days to maturity. Average across years, plants under WR reached to maturity earlier than PR and NR, albeit difference was marginal. Weed management did not influence days to maturity in Year 1 but plants under MW reached to maturity earlier in Year 2 and Year 3. Two- and three-way interaction effects of tillage, residue and weed managements were not significant on days to maturity (Supplementary Table 2). 
Table 2. Days to heading (GS 59) and physiological maturity (GS 93) of wheat under different tillage, crop residue and weeding managements.

\begin{tabular}{|c|c|c|c|c|c|c|c|c|}
\hline \multirow{2}{*}{ Treatment } & \multicolumn{4}{|c|}{ Days to heading } & \multicolumn{4}{|c|}{ Days to maturity } \\
\hline & Year 1 & Year 2 & Year 3 & Average & Year 1 & Year 2 & Year 3 & Average \\
\hline \multicolumn{9}{|l|}{ Tillage system } \\
\hline Conventional (CT) & 78.2 & $75.6 b$ & $78.7 \mathrm{~b}$ & $77.5 b$ & 122.3 & $120.8 b$ & $122.6 \mathrm{~b}$ & $121.9 \mathrm{~b}$ \\
\hline Zero tillage (ZT) & 79.2 & $76.9 \mathrm{a}$ & $80.8 \mathrm{a}$ & $78.9 \mathrm{a}$ & 122.6 & $121.9 \mathrm{a}$ & $126.3 \mathrm{a}$ & $123.6 \mathrm{a}$ \\
\hline \multicolumn{9}{|l|}{ Rice residue management } \\
\hline Whole retention (WR) & 78.4 & 75.8 & $78.6 \mathrm{~b}$ & $77.6 \mathrm{~b}$ & $122.2 \mathrm{a}$ & $120.9 b$ & $124.0 \mathrm{~b}$ & $122.4 \mathrm{c}$ \\
\hline Partial retention (PR) & 79.1 & 76.0 & $79.9 \mathrm{ab}$ & $78.3 \mathrm{a}$ & $122.8 b$ & $121.3 \mathrm{~b}$ & $124.3 b$ & $122.8 \mathrm{~b}$ \\
\hline No retention (NR) & 78.5 & 76.9 & $80.7 \mathrm{a}$ & $78.7 \mathrm{a}$ & $122.4 \mathrm{ab}$ & $121.9 \mathrm{a}$ & $125.1 \mathrm{a}$ & $123.1 \mathrm{a}$ \\
\hline \multicolumn{9}{|l|}{ Weed management } \\
\hline Manual weeding (MW) & 78.7 & 76.1 & 79.3 & 78.0 & 122.6 & $121.1 \mathrm{~b}$ & $124.2 \mathrm{~b}$ & $122.6 b$ \\
\hline Chemical weeding (CW) & 78.6 & 76.4 & 80.1 & 78.4 & 122.4 & $122.7 \mathrm{a}$ & $124.7 \mathrm{a}$ & $122.9 \mathrm{a}$ \\
\hline Average & 78.7B & $76.2 \mathrm{C}$ & 79.7A & & $122.5 \mathrm{C}$ & $121.4 \mathrm{~B}$ & $124.4 \mathrm{~A}$ & \\
\hline
\end{tabular}

Note: Different lowercase letters within a column indicate significant difference $(P<0.05)$ between sub-plot treatments within main-plot crop management treatment. Different uppercase letters within a row of annual mean values (last row) indicate significant difference among the study years within each crop phenological stage.

\subsection{Yield attributes of wheat at harvest}

Tillage systems did not influence length of ear-head in Year 2 (Table 3) but ear-heads under ZT were longer than CT in Year 1, Year 3, and averaged across three years. Among the residue management treatments, WR had the longest ear-heads and NR had the shortest ear-heads in all three years. Weed management had significant influence on the length of ear-heads as longer ear-heads were recorded under MW than $\mathrm{CW}$ in all individual years as well as averaged across three years. Interaction effect between tillage and weed management was significant as $\mathrm{CW}$ under ZT system had the longest ear- heads but the same weed management under CT system had the shortest ear-heads (Supplementary Tables 2 and 4).

Number of grains per ear-head was not influenced by tillage, residue and weed managements and their interactions in any years (Table 3). Weight of 1000 grains was significantly higher under the CT system than in ZT in Year 1 as well as averaged across years (Table 3). Weight of 1000 grains was not influenced by residue and weed managements in any of the three study years. Interaction effect of residue and weed management was significant. No significant effect of weed management was observed between WR and PR residue managements while the effect was significant under NR residue management with more weight of 1000 grains under $\mathrm{CW}$ than MW (Supplementary Tables 2 and 3).

Table 3. Yield attributes of wheat under different tillage, crop residue and weeding managements.

\begin{tabular}{|c|c|c|c|c|c|c|c|c|c|c|c|c|}
\hline \multirow{2}{*}{ Treatment } & \multicolumn{4}{|c|}{ Length of ear-head (cm) } & \multicolumn{4}{|c|}{ No. of grains/ear-head } & \multicolumn{4}{|c|}{1000 grain weight $(g)$} \\
\hline & Year 1 & Year 2 & Year 3 & Average & Year 1 & Year 2 & Year 3 & Average & Year 1 & Year 2 & Year 3 & Average \\
\hline \multicolumn{13}{|l|}{ Tillage system } \\
\hline Conventional (CT) & $10.7 \mathrm{~b}$ & 9.7 & $11.3 \mathrm{~b}$ & $10.6 b$ & 33.3 & 37.4 & 39.0 & 36.6 & $50.8 \mathrm{a}$ & 49.7 & 44.6 & $48.3 \mathrm{a}$ \\
\hline Zero tillage (ZT) & $11.2 \mathrm{a}$ & 9.9 & $12.0 \mathrm{a}$ & $11.1 \mathrm{a}$ & 39.0 & 37.5 & 39.6 & 38.7 & $43.6 b$ & 47.5 & 43.2 & $44.8 \mathrm{~b}$ \\
\hline \multicolumn{13}{|l|}{ Rice residue management } \\
\hline Whole retention (WR) & $11.8 \mathrm{a}$ & $10.2 \mathrm{a}$ & $12.0 \mathrm{a}$ & $11.3 \mathrm{a}$ & 39.3 & 38.1 & 40.1 & 39.2 & 46.0 & 48.8 & 44.8 & 46.5 \\
\hline Partial retention (PR) & $10.9 \mathrm{~b}$ & $9.8 \mathrm{~b}$ & $11.7 \mathrm{~b}$ & $10.8 \mathrm{~b}$ & 34.6 & 37.6 & 39.4 & 37.2 & 46.5 & 48.7 & 43.8 & 46.3 \\
\hline No retention (NR) & $10.2 \mathrm{c}$ & $9.4 \mathrm{c}$ & $11.3 \mathrm{c}$ & $10.3 \mathrm{c}$ & 34.5 & 36.7 & 38.5 & 36.6 & 49.0 & 48.3 & 43.1 & 46.8 \\
\hline \multicolumn{13}{|l|}{ Weed management } \\
\hline Manual (MW) & $11.0 \mathrm{a}$ & $9.9 \mathrm{a}$ & $11.8 \mathrm{a}$ & $10.9 \mathrm{a}$ & 36.1 & 37.6 & 39.5 & 37.8 & $45.2 b$ & 49.5 & 44.2 & 46.3 \\
\hline Chemical (CW) & $10.8 \mathrm{~b}$ & $9.7 \mathrm{~b}$ & $11.6 \mathrm{~b}$ & $10.7 \mathrm{~b}$ & 36.2 & 37.3 & 39.1 & 37.5 & $49.2 \mathrm{a}$ & 47.7 & 43.6 & 46.8 \\
\hline Average & $10.9 \mathrm{~B}$ & $9.8 \mathrm{C}$ & $11.7 \mathrm{~A}$ & & 36.1 & 37.5 & 39.3 & & $47.2 \mathrm{AB}$ & $48.6 \mathrm{~A}$ & $43.9 \mathrm{~B}$ & \\
\hline
\end{tabular}

Note: Different lowercase letters within a column indicate significant difference $(P<0.05)$ between sub-plot treatments within main-plot crop management treatment. Different uppercase letters within a row of annual mean values (last row) indicate significant difference among the study years within each crop yield parameter.

\subsection{Grain yield}

Grain yield was affected by tillage systems only in Year 1 as higher yield was recorded under CT than in ZT (Table 4). Likewise, averaged across three years, grain yield under CT was significantly higher than under the ZT system. Residue management significantly affected grain yield in Year 2 and Year 3, and averaged across three years, as the highest yield was recorded under WR management. Although grain yield of wheat was not significantly different under PR and NR managements, there was a clear trend of increasing grain yield with increased level of rice residue retention. Grain yield was not influenced by weed management methods in any years. Interaction effect of rice residue and weed management was significant as no significant difference of weed management method was seen under PR and NR residue managements, whereas MW had significantly higher yield than CW under WR (Supplementary Tables 2, 3). Averaged across treatments, grain yield of wheat was statistically similar among the three study years. 
Table 4. Grain yield of wheat $\left(\mathrm{t} \mathrm{ha}^{-1}\right)$ under different tillage, crop residue and weeding management practices.

\begin{tabular}{lllll}
\hline Treatments & Year 1 & Year 2 & Year 3 & Average \\
\hline Tillage system & & & & \\
$\quad$ Conventional (CT) & $2.4 \mathrm{a}$ & 2.5 & 2.3 & $2.4 \mathrm{a}$ \\
$\quad$ Zero tillage (ZT) & $2.1 \mathrm{~b}$ & 2.3 & 2.3 & $2.2 \mathrm{~b}$ \\
& & & & \\
Rice residue management & & & & \\
$\quad$ Whole retention (WR) & 2.3 & $2.6 \mathrm{a}$ & $2.5 \mathrm{a}$ & $2.5 \mathrm{a}$ \\
$\quad$ Partial retention (PR) & 2.2 & $2.4 \mathrm{~b}$ & $2.3 \mathrm{~b}$ & $2.3 \mathrm{~b}$ \\
$\quad$ No retention (NR) & 2.2 & $2.2 \mathrm{~b}$ & $2.1 \mathrm{~b}$ & $2.2 \mathrm{~b}$ \\
& & & & \\
Weed management & & & & \\
$\quad$ Manual weeding (MW) & 2.2 & 2.4 & 2.4 & 2.3 \\
$\quad$ Chemical weeding (CW) & 2.3 & 2.4 & 2.3 & 2.3 \\
$\quad$ & 2.3 & 2.4 & 2.3 & \\
Average & & & & \\
\hline
\end{tabular}

Note: Different lowercase letters within a column indicate significant treatment difference $(P<0.05)$ within each crop management treatment.

\section{Discussion}

In this study, we examined the effects of tillage, rice residue and weed management methods on plant growth, yield and yield attributes of wheat cultivated in the Southern Plains (Terai) of Nepal under rice-wheat cropping system. The effect of tillage systems on grain yield was minimal as significant difference was observed only in Year 1with $0.3 \mathrm{tha}^{-1}$ higher grain yield under CT than the ZT system. The minimal difference of CT and ZT systems on wheat grain yield are in accordance with results from previous field experiments in the IGP (Sapkota et al., 2014). Although higher infestation of weeds under ZT may lower yields, weeds were effectively controlled under both tillage systems in this study. Likewise, increased availability of soil moisture is more likely under ZT, which is the most critical factor for wheat production in the IGP, might have offset yield reductions caused by other factors to achieve similar yields between $\mathrm{ZT}$ and CT. Despite similar yields under two tillage systems, a ZT system can be more profitable than CT system due to lower costs incurred in field preparation (Choudhary \& Behera 2013; Jain et al. 2007). Future research should address the economic analysis of tillage systems for wheat production in this study region.

The key finding of this study is the increasing grain yield with an increased proportion of rice residue retention during the second and third study years. These results corroborate the findings from previous studies in the IGP that mostly reported improved yields of wheat grain when rice straw was retained in the field as compared to straw burning or removal (Brar, Condon, Evans \& Singh, 2010; Pathak, Singh, Bhatia \& Jain, 2006; Ram et al., 2013). Although residues are good sources of plant nutrients for the subsequent crops, lack of synchronization between mineralization of nutrients from decomposing biomass and crop demand often reduce the nutrient value of crop residues (Singh et al., 2010). Such lack of synchronization generally occurs after incorporation of cereal residues since they decompose slowly due to high $\mathrm{C} / \mathrm{N}$ ratio and high lignin content (Singh et al., 2010). The insignificant effect of residue management during the first year of the study might be due to slower rates of biomass decomposition and nutrient transfer from decomposing rice residue to wheat. However, there was a clear positive relation between wheat grain yield and levels of rice residue incorporation in successive years, which might be related to increased soil accumulation of nutrients in crop production systems with increasing level of residue retentions.

Overall, the results in this study indicated that rice residue retention can improve wheat grain yields in the long run. Grain yield and yield attributes were not influenced by interaction effects of tillage and residue managements. This means that although rice residue retention can be a challenge for seed bed preparation of wheat under a ZT system, the retained residue can add economic values in the long run. In addition to grain yield, soil C, moisture levels, and microbial activities were expectedly increased with increased retention proportion of rice residue (Wang et al., 2015). Overall, the results from this study demonstrated the benefit of retaining rice straw in the field rather than removing it from the crop production system.

Our results indicate that herbicide application can be as effective as manual weeding in managing weeds in wheat agroecosystems. Previous studies in the IGP also documented effectiveness of 2,4-D and sulfosulfuron, the herbicides applied in this study, in managing weeds under both ZT and CT systems (Chhokar, Sharma, Chauhan \& Mongia, 2006; Usman et al., 2010). The comparable effectiveness of herbicide application for weed management in wheat is promising as the existing manual weed management option is becoming less viable in Nepal due to increasing labor shortage. Nevertheless, resistance management and environmental impact of herbicides must be taken into account while devising profitable wheat production systems in the western Terai region of Nepal.

\section{Conclusions}

The results in this study indicated that a zero-tillage system can be as equally effective as a conventional tillage system for wheat production in rice-wheat rotation. Similarly, the results showed positive impacts of rice residue retention on wheat grain yield. Therefore, leaving rice residues in the field is recommended as a best management practice since residue retention, which is generally recommended as an environmentally and ecologically sustainable production system, also improved grain yields of wheat. Our results also concluded that herbicide application could be equally effective as the manual method of weed control.

\section{References}

Brar, N. K., Condon, J., Evans, J., \& Singh, Y. (2010). Nitrogen management in wheat sown in rice straw as mulch in North West India. In Proceedings of the 19th world congress of soil science, ed. R. Gikes, (pp. 206209). Brisbane, Australia.

Chhokar, R. S., Sharma, R. K., Chauhan, D. S., \& Mongia, A. D. (2006). Evaluation of herbicides against Phalaris minor in wheat in north-western Indian plains. Weed Research, 46, 40-49.

Choudhary, R. L., \& Behera, U. K. (2013). Effect of sequential tillage practices and nitrogen levels on energy relations and use efficiencies of irrigation water and $\mathrm{N}$ in maize (Zea mays) - wheat (Triticum aestivum) cropping system. Indian Journal of Agronomy, 58, 2-34.

Erenstein, O., \& Laxmi, V. (2008). Zero tillage impacts in India's rice-wheat systems: A review. Soil and Tillage Research, 100, 1-14. 
Gangwar, K. S., Singh, K. K., Sharma, S. K., \& Tomar, O. K. (2006). Alternative tillage and crop residue management in wheat after rice in sandy loam soils of Indo - Gangetic plains. Soil and Tillage Research, 88, $242-252$.

Gathala, M. K., Kumar, V., Sharma, P. C., Saharawat, Y. S., Jat, H. S., Singh, M., ... Sharma, S. (2013). Optimizing intensive cereal-based cropping systems addressing current and future drivers of agricultural change in the northwestern Indo-Gangetic Plains of India. Agriculture, Ecosystems \& Environment, 177, 85-97.

Gupta P. K., Sahai, S., Singh, N., Dixit, C. K., Singh, D. P., Sharma, C., ... Garg, S. C. (2004) Residue burning in rice-wheat cropping system: Causes and implications. Current Science, 87, 1713-1717.

Hobbs, P. R., \& Giri, G. S. (1997). Reduced and zero-tillage options for establishment of wheat after rice in South Asia. In Wheat: Prospects for Global Improvement (pp. 455-465). Springer, Dordrecht.

Jain, N., Jain, V., Mishra, J. S., \& Kewat, M. L. (2007). Effect of tillage packages and herbicides on energy and economics of wheat in transplanted rice (Oryza sativa)-wheat (Triticum aestivum) system. Indian Journal of Agricultural Sciences, 77, 174-76.

Khadka, D., Lamichhane, S., Thapa, B., Rawal, N., Chalise, D. R., Vista, S. P., \& Lakhe, L. (2015). Assessment of soil fertility status and preparation of their maps of national wheat research program, Bhairahawa, Nepal. In Proceedings of the Second National Soil Fertility Research Workshop, (pp. 330-340)

Mandal, K. G., Misra, A. K., Hati, K. M., Bandyopadhyay, K. K., Ghosh, P. K., \& Mohanty, M. (2004). Rice residue-management options and effects on soil properties and crop productivity. Journal of Food Agriculture and Environment, 2, 224-231.

Mathew, R. P., Feng, Y., Githinji, L., Ankumah, R., \& Balkcom, K. S. (2012). Impact of no-tillage and conventional tillage systems on soil microbial communities. Applied and Environmental Soil Science, 2012, 1-10.

Ministry of Agriculture Development (2017). Statistical information on Nepalese Agriculture 2015/2016. Agri Statistics Section, Monitoring, Evaluation and Statistics Division, Ministry of Agricultural Development, Singha Durbar, Kathmandu, Nepal.

Nawaz, A., Farooq, M., Lal, R., Rehman, A., Hussain, T., \& Nadeem, A. (2017). Influence of sesbania brown manuring and rice residue mulch on soil health, weeds and system productivity of conservation rice-wheat systems. Land Degradation \& Development, 28, 1078-1090.

Pathak, H., Ladha, J. K., Aggarwal, P. K., Peng, S., Das, S., Singh, Y., ... Aggarwal, H. P. (2003). Trends of climatic potential and on-farm yields of rice and wheat in the Indo-Gangetic Plains. Field Crops Research, 80, 223-234.
Pathak, H., Singh, R., Bhatia, A., \& Jain, N. (2006). Recycling of rice straw to improve wheat yield and soil fertility and reduce atmospheric pollution. Paddy and Water Environment, 4, 111.

Pittelkow, C. M., Linquist, B. A., Lundy, M. E., Liang, X., van Groenigen, K. J., Lee, J., ... van Kessel, C. (2015). When does no-till yield more? A global meta-analysis. Field Crops Research, 183, 156-168.

Ram, H., Dadhwal, V., Vashist, K. K., \& Kaur, H. (2013). Grain yield and water use efficiency of wheat (Triticum aestivum L.) in relation to irrigation levels and rice straw mulching in North West India. Agricultural Water Management, 128, 92-101.

Rao, A. N., Wani, S. P., Ahmed, S., Haider Ali, H., \& Marambe, B. (2017). An Overview of Weeds and Weed Management in Rice of South Asia. In Weed Management in Rice in the Asian-Pacific Region, ed. Rao, A. N., \&, Matsumoto, H. (pp. 247-281). Asian-Pacific Weed Science Society (APWSS), The Weed Science Society of Japan, Japan and Indian Society of Weed Science, India.

Sahai, S., Sharma, C., Singh, S. K., \& Gupta, P. K. (2011). Assessment of trace gases, carbon and nitrogen emissions from field burning of agricultural residues in India. Nutrient Cycling in Agroecosystems, 89, 143-157.

Sapkota, T. B., Majumdar, K., Jat, M. L., Kumar, A., Bishnoi, D. K., McDonald, A. J., \& Pampolino, M. (2014). Precision nutrient management in conservation agriculture based wheat production of Northwest India: Profitability, nutrient use efficiency and environmental footprint. Field Crops Research, 155, 233-244.

Singh, Y., Gupta, R. K., Jagmohan, S., Gurpreet, S., Gobinder, S., \& Ladha, J. K. (2010). Placement effects on rice residue decomposition and nutrient dynamics on two soil types during wheat cropping in rice-wheat system in north western India. Nutrient Cycling in Agroecosystems, 88, 471-480.

Singh, J., Singhal, N., Singhal, S., Sharma, M., Agarwal, S., \& Arora, S. (2018). Environmental implications of rice and wheat stubble burning in north-western states of India. In Advances in Health and Environment safety (pp. 47-55). Springer, Singapore.

Timsina, K. P., Ghimire, Y. N., Gauchan, D., Subedi, S., \& Adhikari, S. P. (2018). Lessons for promotion of new agricultural technology: a case of Vijay wheat variety in Nepal. Agriculture \& Food Security, 7, 63.

Usman, K., Khalil, S. K., Khan, A. Z., Khalil, I. H., \& Khan, M. A. (2010). Tillage and herbicides impact on weed control and wheat yield under ricewheat cropping system in Northwestern Pakistan. Soil and Tillage Research, 110, 101-107.

Wang, W., Lai, D. Y. F., Wang, C., Pan, T., \& Zeng, C. (2015). Effects of rice straw incorporation on active soil organic carbon pools in a subtropical paddy field. Soil and Tillage Research, 152, 8-16.

Zadoks, J. C., Chang, T. T., \& Konzak, C. F. (1974). A decimal code for the growth stages of cereals. Weed Research, 14, 415-421. 

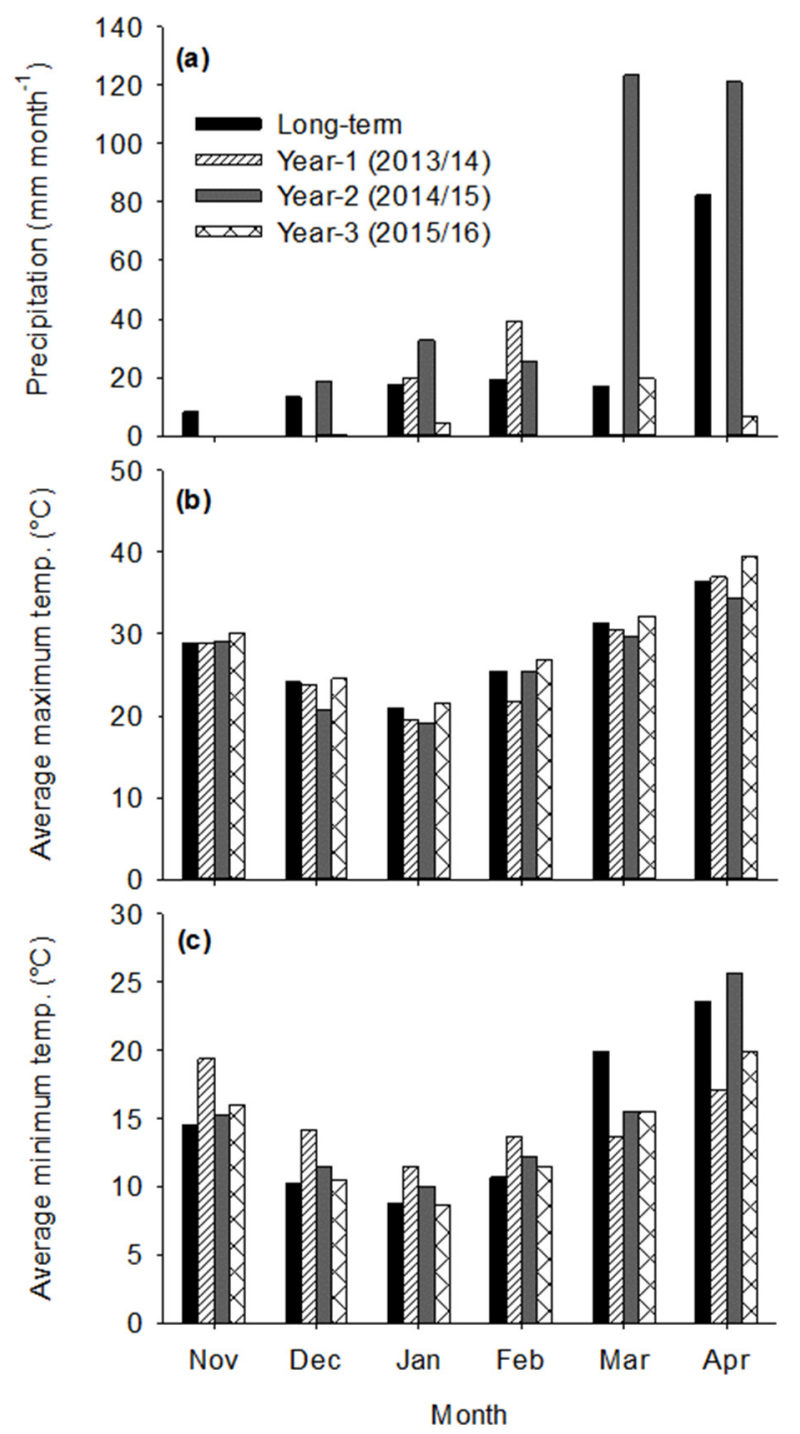

Supplementary Figure 1. Mean monthly values of (a) total precipitation (b) maximum daily temperature, and (c) minimum daily temperature in the study area during the growing seasons of three study years and long-term averages (1985-2015). 
Supplementary Table 1: Timeline of field operations during the study.

\begin{tabular}{|c|c|c|c|c|}
\hline Field operations & Year 1 & Year 2 & Year 3 & Remark \\
\hline Glyphosate (herbicide) spray & 2 Dec 2013 & 27 Nov 2014 & 21 Nov 2015 & CW plots \\
\hline Sowing & 15 Dec 2013 & 6 Dec 2014 & 29 Nov 2015 & All plots \\
\hline Irrigation & 6 Jan 2014 & 28 Dec 2014 & 25 Dec 2015 & All plots \\
\hline Irrigation & 30 Feb 2014 & 21 Feb 2015 & 28 Jan 2016 & All plots \\
\hline Urea top-dressing & 12 Jan 2014 & 3 Jan 2015 & $29 \operatorname{Dec} 2015$ & All plots \\
\hline 2, 4-D (herbicide) spray & 16 Jan 2014 & - & - & CW plots \\
\hline Sulfosulfuron (herbicide) spray & - & 9 Jan 2015 & 1 Jan 2016 & CW plots \\
\hline Nuvan (insecticide) spray & - & - & 2 March 2016 & CW plots \\
\hline Harvesting & 16 April 2014 & 7 April 2015 & 4 April 2016 & All plots \\
\hline
\end{tabular}

CW: Chemical weeding

Supplementary Table 2. Significance ( $P$-values) of the effects of year, tillage, residue and weed managements and their interactions on yield and yield attributes of wheat. The $P$-values are presented with bold fonts if analysis of variance showed significant difference $(P<0.05)$.

\begin{tabular}{|c|c|c|c|c|c|c|c|c|}
\hline Effect & $\begin{array}{l}\text { Days to } \\
\text { Heading }\end{array}$ & $\begin{array}{l}\text { Days to } \\
\text { Maturity }\end{array}$ & $\begin{array}{l}\text { Plant } \\
\text { Height }\end{array}$ & $\begin{array}{l}\text { Length of } \\
\text { ear-head }\end{array}$ & $\begin{array}{l}\text { Tiller } \\
\text { number }\end{array}$ & $\begin{array}{l}1000 \text { grain } \\
\text { weight }\end{array}$ & $\begin{array}{l}\text { No. of Grain } \\
\text { per ear-head }\end{array}$ & $\begin{array}{l}\text { Grain } \\
\text { yield }\end{array}$ \\
\hline Year & 0.00 & 0.00 & 0.00 & 0.00 & 0.03 & 0.05 & 0.56 & 0.13 \\
\hline Tillage & 0.00 & 0.00 & 0.03 & 0.00 & 0.01 & 0.01 & 0.36 & 0.01 \\
\hline Residue & 0.02 & 0.00 & 0.00 & 0.00 & 0.12 & 0.81 & 0.16 & 0.00 \\
\hline Weed & 0.10 & 0.00 & 0.01 & 0.00 & 0.65 & 0.38 & 0.23 & 0.13 \\
\hline Year×Tillage & 0.35 & 0.00 & 0.35 & 0.06 & 0.25 & 0.12 & 0.54 & 0.06 \\
\hline Year $\times$ Residue & 0.19 & 0.02 & 0.03 & 0.00 & 0.62 & 0.12 & 0.70 & 0.08 \\
\hline Year×Weed & 0.21 & 0.00 & 0.35 & 0.95 & 0.69 & 0.00 & 0.59 & 0.41 \\
\hline Tillage $\times$ Residue & 0.89 & 0.10 & 0.56 & 0.90 & 0.26 & 0.54 & 0.43 & 0.61 \\
\hline Tillage $\times$ Weed & 0.46 & 1.00 & 0.66 & 0.04 & 0.79 & 0.62 & 0.54 & 0.96 \\
\hline Residue $\times$ Weed & 0.53 & 0.90 & 0.30 & 0.34 & 0.01 & 0.04 & 0.80 & 0.04 \\
\hline Year $\times$ Tillage $\times$ Residue & 0.97 & 0.10 & 0.43 & 0.44 & 0.81 & 0.06 & 0.47 & 0.86 \\
\hline Year $\times$ Tillage $\times$ Weed & 0.53 & 0.90 & 0.39 & 0.03 & 0.86 & 0.31 & 0.44 & 0.96 \\
\hline Year×Residue $\times$ Weed & 0.39 & 0.08 & 0.23 & 0.58 & 0.00 & 0.02 & 0.92 & 0.21 \\
\hline Tillage $\times$ Residue $\times$ Weed & 0.81 & 0.73 & 0.31 & 0.91 & 0.45 & 0.77 & 0.62 & 0.48 \\
\hline Year $\times$ Tillage $\times$ Residue $\times$ Weed & 0.86 & 0.67 & 0.19 & 0.67 & 0.63 & 0.48 & 0.43 & 0.77 \\
\hline
\end{tabular}

Supplementary Table 3. Interaction between rice residue retention and weed management methods on crop growth and yield attributes of wheat. Only significant interaction effect presented in Supplementary Table 2 are presented.

\begin{tabular}{lllll}
\hline Rice residue management & Weed management & $\begin{array}{l}\text { No. of } \\
\text { effective tillers }\end{array}$ & $\begin{array}{l}\text { 1000 grain } \\
\text { weight (g) }\end{array}$ & $\begin{array}{l}\text { Grain yield } \\
\text { (t ha-1) }\end{array}$ \\
\hline Whole retention (WR) & Manual weeding (MW) & $229^{\mathrm{abc}}$ & $46.9^{\mathrm{ab}}$ & \\
& Chemical weeding (CW) & $235^{\mathrm{ab}}$ & $46.2^{\mathrm{ab}}$ & $2.5^{\mathrm{a}}$ \\
& & & $46.5^{\mathrm{ab}}$ & $2.4^{\mathrm{b}}$ \\
Partial retention (PR) & Manual weeding (MW) & $239^{\mathrm{a}}$ & $46.1^{\mathrm{ab}}$ & $2.3^{\mathrm{bc}}$ \\
& Chemical weeding (CW) & $217^{\mathrm{bc}}$ & & $2.3^{\mathrm{bc}}$ \\
No retention (NR) & Manual weeding (MW) & $209^{\mathrm{c}}$ & $45.5^{\mathrm{b}}$ & \\
& Chemical weeding (CW) & $219^{\mathrm{abc}}$ & $46.9^{\mathrm{ab}}$ & $2.2^{\mathrm{c}}$ \\
\hline
\end{tabular}

Different lowercase letters within a column indicate significant difference in means across residue retention and weed management combination treatments.

Supplementary Table 4. Interaction between tillage system and weed managements on ear-head length of winter wheat. Only significant interaction effect presented in Supplementary Table 2 is presented.

\begin{tabular}{lll}
\hline Tillage system & Weed management & Length of ear-head (cm) \\
\hline Conventional (CT) & & \\
& Manual weeding (MW) & $10.7^{\mathrm{c}}$ \\
& Chemical weeding (CW) & $10.4^{\mathrm{d}}$ \\
Zero tillage (ZT) & & \\
& Manual weeding (MW) & $11.1^{\mathrm{a}}$ \\
& Chemical weeding (CW) & $11.0^{\mathrm{b}}$ \\
\hline
\end{tabular}

Different lowercase letters within a column indicate significant difference in means across tillage and weed management combination treatments. 